\title{
Complexometric Determination of Clodronate in Aqueous Solutions and Urine
}

\author{
Vesa Virtanen,* Jouni Pursiainen and Lauri H. J. Lajunen \\ Department of Chemistry, University of Oulu, Linnanmaa, SF-90570 Oulu, Finland
}

\begin{abstract}
Virtanen, V., Pursiainen, J. and Lajunen, L. H. J., 1993. Complexometric Determination of Clodronate in Aqueous Solutions and Urine. - Acta Chem. Scand. 47: 1071-1077. (C) Acta Chemica Scandinavica 1993.
\end{abstract}

\begin{abstract}
Three different procedures for the determination of clodronate by means of Th-EDTA-XO or Th-DCTA-XO (XO = xylenol orange) complexes are presented. According to the UV-VIS and ${ }^{13} \mathrm{C}$ NMR measurements, $\mathrm{XO}$ is quantitatively replaced by the clodronate anion in the mixed ligand Th-EDTA-XO or Th-DCTA-XO complexes in slightly acidic solutions. This ligand replacement reaction can be applied to the determination of traces of clodronate. Procedures studied involve visual complexometric titration, spectrophotometric titration and conventional spectrophotometric determination. By visual complexometric titration it is possible to determine clodronate directly in human urine with acceptable accuracy and precision in the range $0.5-2.5 \mathrm{mg} \mathrm{l}^{-1}$. By diluting more concentrated urine samples $1: 10$ with water, samples of up to $80 \mathrm{mg} \mathrm{l}^{-1}$ can be determined with acceptable accuracy and precision. The working range of the method is linear up to $16 \mathrm{mg} \mathrm{l}^{-1}$ in aqueous solutions with the RSD-value varying between 0.7 and $3.8 \%$. Interference caused by the major substances of human urine on the determination were studied.
\end{abstract}

Clodronic acid belongs to a group of bisphosphonates of the type P-C-P. ${ }^{1-4}$ Bisphosphonates are a class of ligands that are chemically related to, and mimic the physiological behaviour of, pyrophosphates. Most important, both pyrophosphate and bisphosphonate ligands have very high affinity for calcium(II) in homogeneous solutions and at the surfaces of minerals and bone. Clodronate, which is the disodium salt of clodronic acid [(dichloromethylene)bisphosphonic acid], is a synthetic analogue of pyrophosphate, which, together with conventional cancer therapy, has been used successfully for the treatment of hypercalcaemia related to osteolytic metastases and malignances. ${ }^{5}$

The quantitative determination of clodronate in biological samples involves several difficulties. It is highly polar and forms stable, soluble metal complexes with a number of cations. Even alkali metals form soluble compounds with clodronate. ${ }^{6}$ Inorganic anions, commonly present in body fluids, will cause severe interference with most of the methods presented for the direct determination of bisphosphonates in real samples. Hence, a separation process is often needed. Recently, we reported on the HPLC and spectrophotometric determinations of clodronate in aqueous solutions. ${ }^{7,8}$ The aim of these investigations is to develop a rapid, simple and reliable method for the direct determination of clodronate to be

\footnotetext{
* To whom correspondence should be addressed.
}

used in quality control, purity determinations and patient care. The present paper describes studies on the complexometric determination of clodronate in aqueous solutions and urine.

\section{Experimental}

Apparatus. A Pye Unicam SP 8-100 UV spectrometer and a Philips PU 8700 UV spectrometer were used for the absorbance measurements. ${ }^{13} \mathrm{C}$ NMR spectra were recorded on a Bruker AM-200 spectrometer at $25^{\circ} \mathrm{C}$.

Reagents. Thorium nitrate and ethylenediamine (EDA) were obtained from Fluka AG, EDTA and Xylenol Orange from Merck, and clodronate from Leiras Oy. ${ }^{9}$ The thorium stock solution $(4.0 \mathrm{mM})$ was prepared by dissolving $1.104 \mathrm{~g}$ of $\mathrm{Th}\left(\mathrm{NO}_{3}\right)_{4} \cdot 4 \mathrm{H}_{2} \mathrm{O}$ in $20 \mathrm{ml}$ of $2.0 \mathrm{M}$ nitric acid and by diluting to $500 \mathrm{ml}$ with water. The EDTA stock solution $(4.0 \mathrm{mM})$ was obtained by dissolving $0.744 \mathrm{~g}$ of EDTA in $500 \mathrm{ml}$ of water. The EDA solution $(0.6 \mathrm{M})$ was prepared by adding $10.1 \mathrm{ml}$ of EDA to ice-cold water, followed by adding $15 \mathrm{ml}$ of concentrated hydrochloric acid slowly with stirring. The temperature was kept below $20^{\circ} \mathrm{C}$. The $\mathrm{pH}$ was adjusted to 7.3 with diluted hydrochloric acid and the solution was diluted to $250 \mathrm{ml}$ with water. ${ }^{10}$ The XO indicator solution $(0.05 \%)$ was prepared by dissolving $50 \mathrm{mg}$ of $\mathrm{XO}$ in $100 \mathrm{ml}$ of water. The hexamethylenetetramine (hexamine) solution $(20 \%)$ was prepared by dissolving $20 \mathrm{~g}$ of hexamine in 
$100 \mathrm{ml}$ of water. Only distilled and demineralized water was used. Urine samples were obtained from healthy human volunteers not receiving any medical treatment.

\section{Procedures of the NMR and UV-VIS spectroscopic measurements}

NMR measurement solutions. Solutions containing plain XO, Th-EDTA-XO complex and Th-EDTA-XO + clodronate in ethylenediamine (EDA) buffer solution were prepared. The plain XO solution was prepared by taking $2.1 \mathrm{ml}$ of $60 \mathrm{mM} \mathrm{XO}$ and adding $1 \mathrm{ml}$ of $0.6 \mathrm{M}$ EDA solution. The $\mathrm{pH}$ was adjusted to $6.2 \pm 0.1$ with dilute $\mathrm{HCl}$. The sample was diluted up to $10 \mathrm{ml}$ with deuterium oxide in order to get plain XO buffered with EDA solution. Th-EDTA-XO and Th-EDTA-XO + clodronate solutions were prepared by taking an aliquot of $2.1 \mathrm{ml}$ of $60 \mathrm{mM} \mathrm{XO}$ and adding $2 \mathrm{ml}$ of Th-EDTA $(60 \mathrm{mM})$ solution. Then $1 \mathrm{ml}$ of $0.6 \mathrm{M}$ EDA buffer solution was added and the $\mathrm{pH}$ was adjusted to $6.2 \pm 0.1$ with dilute $\mathrm{HCl}$ solution. The samples were diluted up to $10 \mathrm{ml}$ with deuterium water. In the Th-EDTA-XO + clodronate solution $1 \mathrm{ml}$ of solution containing $20 \mathrm{mM}$ clodronate was added before diluting up to $10 \mathrm{ml}$. The $\mathrm{pH}$ was chosen to be $6.2 \pm 0.1$ because the range $6.2 \pm 0.1$ is the most common one when the solutions are being made.

The ${ }^{13} \mathrm{C}-\left\{{ }^{1} \mathrm{H}\right\}$ NMR chemical shifts are referenced to the signal of the methyl carbon of acetone $(30.5 \mathrm{ppm}$, in $\mathrm{D}_{2} \mathrm{O} / \mathrm{H}_{2} \mathrm{O}$ solution), which was used as an external standard. Typically 13000 scans were needed to obtain the spectra.

UV measurement solutions. Plain $\mathrm{XO}$ and Th-EDTA-XO solutions were obtained by preparing similar $\mathrm{XO}$ and Th-EDTA-XO solutions as in NMR measurements solutions and diluting them 1:200 with water. Into another similar solution as Th-EDTA-XO an aliquot of $0.9 \mathrm{ml}$ of $30 \mathrm{mM}$ clodronate solution was added before the dilution process. The $\mathrm{pH}$ of the solutions were adjusted to 6.23 . The spectra were recorded between 300 and $650 \mathrm{~nm}$, with a scanspeed of $500 \mathrm{~nm} \mathrm{~min}^{-1}$.

\section{Procedures for the complexometric titration (method A)}

Aqueous solutions. An aliquot of $2 \mathrm{ml}$ of Th solution (400, 40 or $8 \mu \mathrm{M}$ ) was placed into the titration cup, $4 \mathrm{ml}$ of $0.4 \mathrm{mM}$ EDTA solution was added, and the $\mathrm{pH}$ adjusted to $6.0-6.3$ with $1 \mathrm{ml}$ of $0.6 \mathrm{M}$ EDA buffer solution and the amount of $0.1 \mathrm{M} \mathrm{HCl}$ solution needed. Then $0.1 \mathrm{ml}$ of XO indicator solution was added. The solution was titrated with a clodronate solution to be analyzed. The Th solution was standardized with a $\mathrm{Na}_{2} \mathrm{Cl}_{2} \mathrm{MBP}$ standard solution. The $\mathrm{Na}_{2} \mathrm{Cl}_{2} \mathrm{MBP}$ standard solution was prepared by dissolving a known amount of $\mathrm{Na}_{2} \mathrm{Cl}_{2} \mathrm{MBP}$ $(100 \%$ pure) in water. The salt used had been used as a reference standard material in the pharmaceutical factory manufacturing clodronate.

Urine solutions. $2 \mathrm{ml}$ of Th solution $(80 \mu \mathrm{M})$ were placed into the titration cup and then $1 \mathrm{ml}$ of $0.4 \mathrm{mM}$ EDTA solution was added. The $\mathrm{pH}$ was adjusted to $6.1-6.3$ with $1 \mathrm{ml}$ of $0.6 \mathrm{M}$ EDA solution and the amount of $0.1 \mathrm{M} \mathrm{HCl}$ solution needed. Then $0.1 \mathrm{ml}$ of XO solution was added. The solution was titrated with urine solution containing clodronate to be determined. $3 \mathrm{ml}$ of $0.1 \mathrm{mM}$ clodronate solution were added to the urine sample solution $(20 \mathrm{ml})$ in order to sharpen the end-point. The solution was diluted to $50 \mathrm{ml}$ with water in order to diminish the strong colour of the matrix. The end-point was determined visually in both aqueous and urine solutions with the help of a reference solution. $6 \mathrm{ml}$ of $0.1 \mathrm{mM}$ clodronate solution are added to a more concentrated urine sample $(10 \mathrm{ml})$ in order to sharpen the end-point. The solution was diluted to $100 \mathrm{ml}$ with water. All urine samples were made by spiking with known amounts of clodronate.

\section{Procedure for the spectrophotometric titration (method B)}

An aliquot of ( 1 or 2 ) $\mathrm{ml}$ of clodronate solution was placed into the titration cup. The test solution was titrated with a standard Th-EDTA-XO solution ( 80 or $8 \mu \mathrm{M}$ Th) using a microburette. Absorbances were measured at $590 \mathrm{~nm}$ using a $10 \mathrm{~mm}$ flow-through-cell. The test solution was circulated with a peristaltic pump. The measured absorbances were corrected according to the dilution. ${ }^{11}$ The end-point of the titration was determined from a titration curve, absorbance vs. volume of titrant added. The titration was reversed compared to the visual complexometric titration because the end-point of the titration is more accurately detected with a spectrophotometer when the colour changes from yellow to red-violet than from red-violet to yellow. This is because at this $\mathrm{pH}$ range part of the free $\mathrm{XO}$ is also red-violet coloured, the end-point detection is not so reliable and the curve is slightly bent.

\section{Procedure for the spectrophotometric method (method C)}

$20 \mathrm{ml}$ of $20 \mu \mathrm{M} \mathrm{Th}\left(\mathrm{NO}_{3}\right)_{4} \cdot 4 \mathrm{H}_{2} \mathrm{O}$ solution were pipetted into a $50 \mathrm{ml}$ volumetric flask, and then $20 \mathrm{ml}$ of $40 \mu \mathrm{M}$ EDTA solution were added. The $\mathrm{pH}$ was adjusted to 6.1-6.3 with $1 \mathrm{ml}$ of EDA buffer solution $(0.6 \mathrm{M})$ and the amount of hydrochloric acid $(0.1 \mathrm{M})$ needed. $1.0 \mathrm{ml}$ of $\mathrm{XO}$ solution was added, and the solution was diluted to $50 \mathrm{ml}$ with water. An aliquot of $15 \mathrm{ml}$ of clodronate solution was then pipetted into a $25 \mathrm{ml}$ volumetric flask, and the $\mathrm{pH}$ was adjusted with EDA and hydrochloric acid. $3 \mathrm{ml}$ of the Th solution were added and the solution was diluted to $25 \mathrm{ml}$. Absorbance was measured at $590 \mathrm{~nm}$ using $20 \mathrm{~mm}$ cuvettes.

\section{Interference studies in urine using method $C$}

Stock solutions of the major substances of human urine were prepared with the concentration limits described by D'Amour. ${ }^{12}$ Aliquots of approximately $5 \mathrm{ml}$ of clodronate $\left(9.0 \mathrm{mg} \mathrm{l}^{-1}\right)$ and $5 \mathrm{ml}$ of major substance (varying concentration) were mixed, and the $\mathrm{pH}$ was adjusted to 
6.1-6.3 with 0.6 M EDA and dilute hydrochloric acid. A blank solution was also made. $10 \mathrm{ml}$ of the Th solution $(4 \mathrm{mM})$ were taken and $20 \mathrm{ml}$ of the EDTA solution ( $4 \mathrm{mM}$ ) were added. The $\mathrm{pH}$ was adjusted with 2 or $5 \mathrm{ml}$ of the EDA solution $(0.6 \mathrm{M})$ or $2 \mathrm{ml}$ of hexamine $(20 \%)$ and diluted with $\mathrm{HCl} .5 \mathrm{ml}$ of $\mathrm{XO}$ were added, and the solution was diluted to $50 \mathrm{ml}$ with water. An aliquot of $5 \mathrm{ml}$ was taken and added to the clodronate + major substance solution. The solution was diluted to $25 \mathrm{ml}$ and the absorbance was measured at $590 \mathrm{~nm}$.

\section{Results and discussion}

The present method is a modified version of the method presented by Pribil and Vesely ${ }^{13}$ for the determination of thorium with (1-hydroxyethylidene)bisphosphonic acid (HEBP). The reactions taking place were earlier ${ }^{10}$ assumed to be (1), (2) or (3).

$$
\begin{aligned}
\text { Th }+ \text { EDTA } \underset{\mathrm{pH} \mathrm{2.5-3.5}}{\longrightarrow} & \text { Th-EDTA } \\
\underset{\mathrm{pH} \mathrm{6.0-6.3}}{\stackrel{\mathrm{xo}}{\longrightarrow}} & \text { Th-EDTA-XO } \\
& \text { (red-violet) }
\end{aligned}
$$
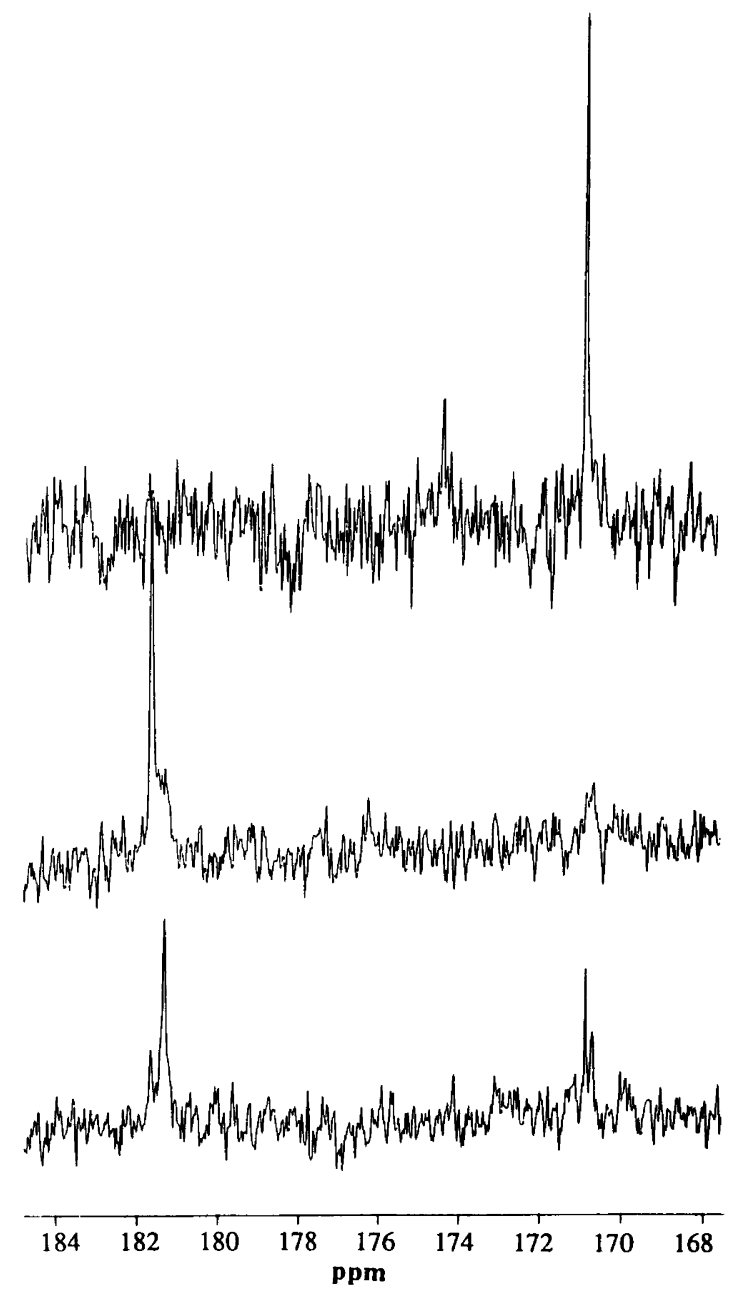<smiles></smiles>

Fig. 1. The structure of Xylenol Orange.

2 Th-EDTA-XO $+\mathrm{Na}_{2} \mathrm{Cl}_{2} \mathrm{MBP}$

$$
\longrightarrow \underset{(\text { yellow })}{(\text { Th-EDTA })_{2}\left(\mathrm{Cl}_{2} \mathrm{MBP}\right)(\mathrm{XO})_{2}}
$$

or

$$
\begin{aligned}
& 2 \text { Th-EDTA-XO }+\mathrm{Na}_{2} \mathrm{Cl}_{2} \mathrm{MBP} \\
& \quad \longrightarrow \mathrm{Th}_{2}(\text { EDTA })_{2}\left(\mathrm{Cl}_{2} \mathrm{MBP}\right)+2 \mathrm{XO}
\end{aligned}
$$

(yellow)

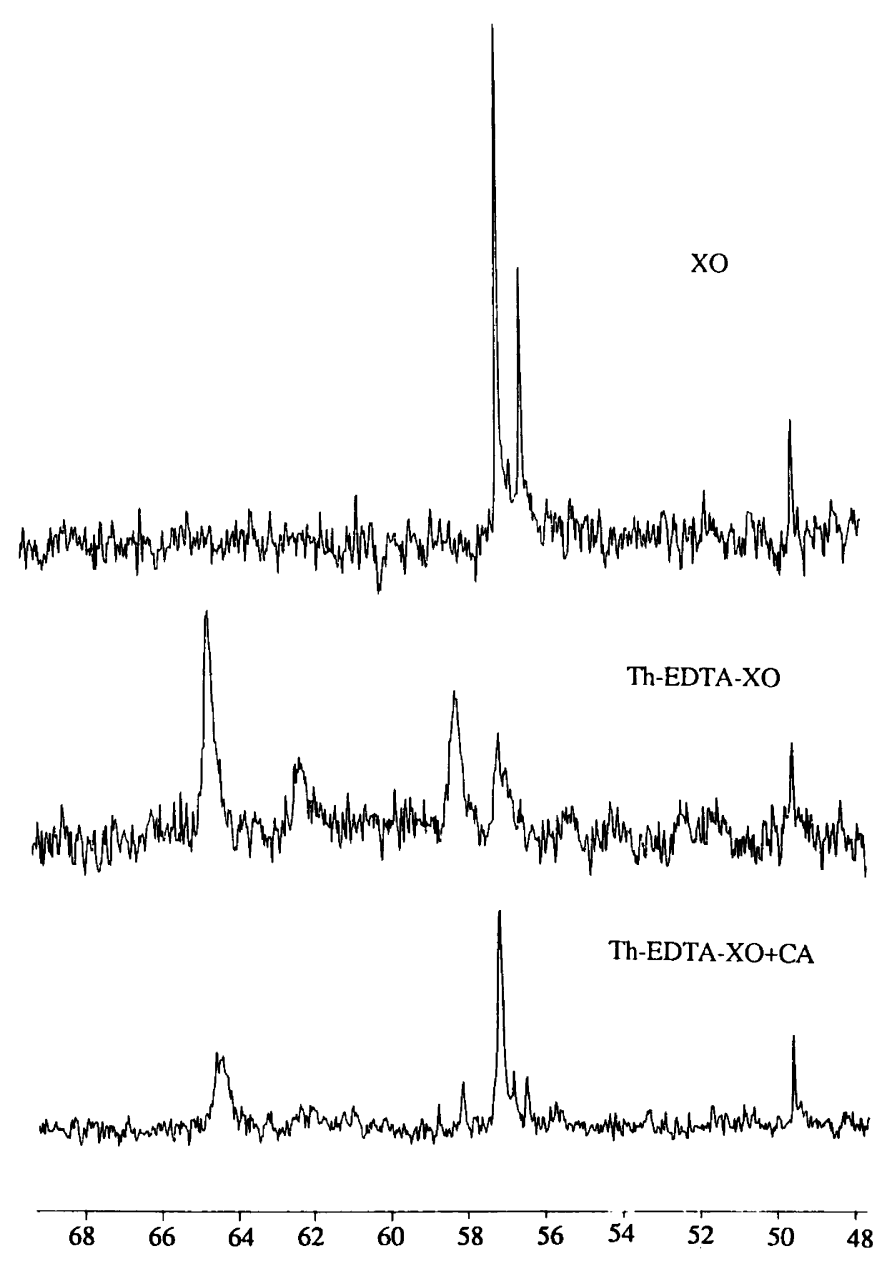

Fig. 2. NMR spectra of plain XO, Th-EDTA-XO and Th-EDTA-XO + clodronate(CA) in EDA buffer solution (pH $6.2 \pm 0.1)$. 
This study was begun by investigating the reaction between Th-EDTA-XO and clodronate. In XO (Fig. 1) the potential complexation sites to $\mathrm{Th}^{4+}$ are the carboxyl, amine, hydroxyl and $\mathrm{SO}_{3} \mathrm{H}$ groups. In the NMR spectra (Fig. 2) of the three solutions (XO, Th-EDTA-XO and Th-EDTA-XO + clodronate in EDA buffer) the peak of the methyl group of $\mathrm{XO}$ is found at $16 \mathrm{ppm}$ and the peak of the buffer solution (EDA) at $39 \mathrm{ppm}$. The NMR spectrum of plain $\mathrm{XO}+$ EDA shows the carboxyl carbon signal at $171 \mathrm{ppm}$, but when the sample contains Th-EDTA this signal has almost entirely disappeared and two peaks at $182 \mathrm{ppm}$ are found. (The carboxyl carbon signals of Th-EDTA are also in this area.) The peaks near $58 \mathrm{ppm}$ belong to the $-\mathrm{CH}_{2}-\mathrm{N}$ carbons near to the carboxyl groups. The formation of the Th-EDTA-XO complex can also be observed here. Thus according to the NMR spectra the complexation of XO occurs through the $\mathrm{N}\left(\mathrm{CH}_{2} \mathrm{COO}^{-}\right)_{2}$ groups. The Th-EDTA-XO solution contained a slight excess of $\mathrm{XO}$, as indicated by the small peaks of free XO.

After addition of clodronate (CA) to the Th-EDTA-XO solution the peaks of free $\mathrm{XO}$ can be seen, indicating that clodronate can replace XO. However, the peaks of coordinated XO and/or EDTA are also present.

In the UV spectrum (Fig. 3 ) the plain XO has a major peak at $434 \mathrm{~nm}$ and a minor peak at $578 \mathrm{~nm}$. These two peaks are caused by the two different forms of $\mathrm{XO}$ at the $\mathrm{pH}$ used (6.23), namely $\mathrm{XO}$ has a $\mathrm{p} K_{\mathrm{a}}$ value of 6.4 and at $\mathrm{pH} 6.23 \mathrm{XO}$ is partially protonated. When Th-EDTA-XO complex is formed, a major peak at $577 \mathrm{~nm}$ is observed. The spectrum of the solution in which clodronate has reacted with Th-EDTA-XO is similar to that of the plain XO. The increased peak at $578 \mathrm{~nm}$ compared to that in the spectrum of plain XO correlates with a slight excess of Th-EDTA-XO. On the basis of these NMR and UV-VIS observations, it could be assumed that clodronate replaces XO in the Th-EDTA-XO complex and the reactions taking place are (1) and (3).

Table 1 shows the results obtained for 10 aqueous and

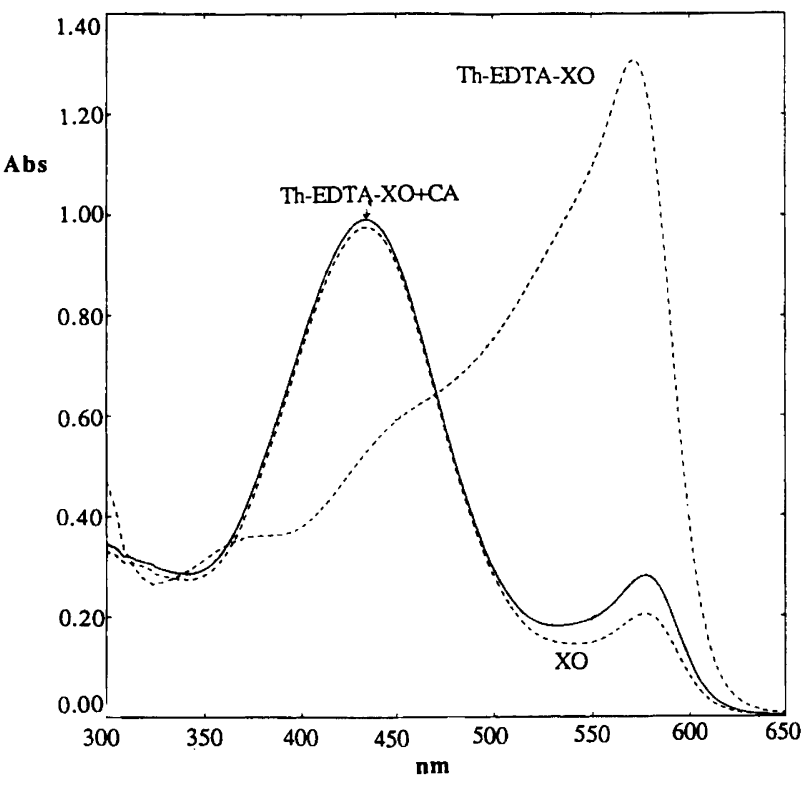

Fig. 3. UV spectra of plain XO, Th-EDTA-XO and Th-EDTA$X O$ + clodronate (CA) in EDA buffer solution ( $\mathrm{pH} \mathrm{6.23)}$.

4 urine samples by visual complexometric titration (method A). The concentration of clodronate varied between 0.1 and $16 \mathrm{mg} \mathrm{l}^{-1}$ in aqueous solutions. For the aqueous test solutions containing clodronate less than $1 \mathrm{mg} \mathrm{l}^{-1}$ the recovery varied between 100 and $106 \%$, and for the solutions containing clodronate from 1 to $16 \mathrm{mg}^{-1}$, the recovery varied between 97 and $112 \%$. The RSD value of the determination of method $A$ varied between 0.7 to $3.8 \%$ in aqueous solution at different concentrations. Urine samples were spiked with clodronate as described earlier, so that each Th test solution consumed $13.33 \mathrm{ml}$ of the sample containing no clodronate (blank solution) before reaching the end-point. The concentration of clodronate in the urine test samples was between 0.45 and $2.52 \mathrm{mg}^{-1}$. More concentrated samples $(20,40$

Table 1. Determination of clodronate by complexometric titration ( $\operatorname{method} A$ ).

\begin{tabular}{|c|c|c|c|c|c|c|}
\hline \multicolumn{4}{|c|}{ Aqueous solutions } & \multicolumn{3}{|c|}{ Urine solutions } \\
\hline \multicolumn{2}{|c|}{ Clodronate $/ \mathrm{mg} \mathrm{|}^{-1}$} & \multirow[b]{2}{*}{ Recovery (\%) } & \multirow[b]{2}{*}{ RSD \% } & \multicolumn{2}{|c|}{ Clodronate $/ \mathrm{mg} \mathrm{I}^{-1}$} & \multirow[b]{2}{*}{ Recovery (\%) } \\
\hline Taken & Found & & & Taken & Found & \\
\hline $\begin{array}{r}0.10 \\
0.20 \\
0.40 \\
0.48 \\
0.96 \\
1.92 \\
4.00 \\
8.00 \\
12.00 \\
16.00\end{array}$ & $\begin{array}{r}0.10 \\
0.21 \\
0.40 \\
0.49 \\
1.02 \\
1.71 \\
4.15 \\
7.85 \\
11.90 \\
15.62\end{array}$ & $\begin{array}{r}100.0 \\
105.0 \\
100.0 \\
102.1 \\
106.3 \\
112.3 \\
103.8 \\
98.1 \\
99.2 \\
97.6\end{array}$ & $\begin{array}{l}3.79 \\
2.37 \\
3.54 \\
\\
0.67 \\
0.65\end{array}$ & $\begin{array}{r}0.45 \\
0.88 \\
1.72 \\
2.52 \\
20.00 \\
40.00 \\
80.00\end{array}$ & $\begin{array}{r}0.42 \pm 0.04^{a} \\
0.86 \pm 0.04^{a} \\
1.69 \pm 0.04^{b} \\
2.56 \pm 0.21^{a} \\
20.73 \pm 2.32^{c} \\
41.71 \pm 2.48^{a} \\
81.67 \pm 2.65^{a}\end{array}$ & $\begin{array}{r}93.3 \\
97.7 \\
99.4 \\
101.6 \\
103.5 \\
104.3 \\
102.1\end{array}$ \\
\hline
\end{tabular}

a Means of double, ${ }^{b}$ triple or ${ }^{c}$ quadruple determinations. 
Table 2. Determination by spectrophotometric titration (method B).

\begin{tabular}{|c|c|c|}
\hline \multicolumn{2}{|c|}{ Clodronate $/ \mathrm{mg} \mathrm{I}^{-1}$} & \multirow[b]{2}{*}{ Recovery (\%) } \\
\hline Taken & Found & \\
\hline $\begin{array}{r}0.54 \\
0.90 \\
1.80 \\
2.25 \\
4.50 \\
90.00\end{array}$ & $\begin{array}{l}0.53 \\
0.88 \\
1.82 \pm 0.04^{a} \\
2.22 \pm 0.07^{a} \\
4.52 \pm 0.09^{a} \\
88.99\end{array}$ & $\begin{array}{r}98.1 \\
97.8 \\
101.1 \\
98.7 \\
100.4 \\
98.9\end{array}$ \\
\hline
\end{tabular}

aeans of double determinations.

and $80 \mathrm{mg} \mathrm{1}^{-1}$ ) were also determined. The recovery varied for urine samples between 93 and $104 \%$.

The usual amounts found in patient urine samples vary between 2 and $100 \mathrm{mg} \mathrm{l}^{-1}$. Amounts up to $250 \mathrm{mg} \mathrm{l}^{-1}$ are also found. The variation is caused by differences in resorption of the medicine into the blood. Patient treatment with either capsules or infusion also causes variation in medicine amounts found in urine samples. ${ }^{14}$ The great amount of the medicine in urine samples makes it possible to dilute samples before determination by titration.

The visual complexometric titration (method A) is a sufficiently accurate and reliable method for the determination of clodronate in aqueous solutions. In urine solutions the strong colour of the matrix makes it difficult to detect the visual end-point accurately. Therefore the urine samples must be diluted with water. The use of this method needs some practice to acquire the necessary skill for the titration.

Table 2 shows the results obtained for the determination of clodronate by method B (spectrophotometric titration, $\lambda=590 \mathrm{~nm}$ ). Urine samples cannot be analyzed with this method because of the strong spectral interference at the measuring wavelength caused by the major substances in human urine.

The calibration graph in Fig. 4 shows that clodronate can be determined by method $\mathrm{C}$ (the spectrophotometric method) in the concentration range $0-3.60 \mathrm{mg}^{-1}$. The correlation coefficient, $r$, of the calibration graph is 0.998 , $r^{2}=0.996$ and the equation of the calibration graph is:

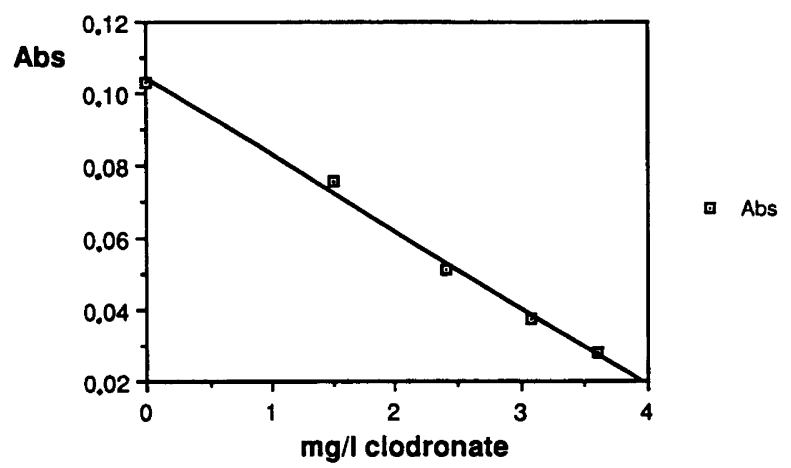

Fig. 4. Spectrophotometric calibration graph of clodronate.
$A=0.1042-0.0214 c$ (where $c$ is in $\mathrm{mg} \mathrm{l}^{-1}$ ). However, by changing the volume of the clodronate solution the concentration range can be altered. Urine samples cannot be analyzed directly by method $\mathrm{C}$ owing to strong spectral interference at the measuring wavelength caused by the urine matrix components.

In human urine the major substances are urea, uric acid, $\mathrm{NH}_{4}^{+}, \mathrm{NaCl}$, sulfate, phosphate and $\mathrm{KCl}^{12}$ The amount of substance varies from $0.4 \mathrm{~g}^{-1}$ of uric acid to $25.0 \mathrm{~g}^{-1}$ of urea. Fig. 5 shows the effects of these substances on the determination of clodronate by the methods using the wavelength $590 \mathrm{~nm}$, which is the wavelength at which the absorbance of the Th-EDTA-XO decreases owing to the reaction with clodronate. Phosphate interferes severely owing to its similar nature to clodronate by reacting with Th-EDTA-XO. Even $1 \mathrm{mg} 1^{-1}$ phosphate in the test solution is enough to cause a strong interference with all three buffer solutions. Urea has a weak effect in EDA buffered solutions, but no interference is observed in solutions buffered with hexamine. Uric acid probably forms a complex with Th-EDTA-XO in EDA $(5 \mathrm{ml})$ and hexamine buffered solutions, but has no effect in solutions containing less EDA. The effect of uric acid increases nearly linearly with increasing amount of uric acid in EDA $(5 \mathrm{ml})$ buffered solutions, but in hexamine solutions the effect increases rapidly up to $200 \mathrm{mg} \mathrm{l}^{-1}$ uric acid and then remains constant. In EDA solutions $\mathrm{NaCl}$ has an increasing effect in small amounts but reaches a constant level. The effect is more severe with solutions buffered with more EDA. With hexamine $\mathrm{NaCl}$ has a constantly increasing interference effect with increasing amounts of $\mathrm{NaCl}$. This is because of a tentative effect of increasing ionic strength. $\mathrm{KCl}$ has no effect in EDA solutions, but in solutions containing hexamine $\mathrm{KCl}$ has a weakly increasing effect on the reaction. Sulfate has a similar effect in all buffer solutions studied. This is probably due to its nature as a polyoxo anion in reacting with Th-EDTA-XO or producing steric hindrance. $\mathrm{NH}_{3}$ has no or little effect when buffered with $5 \mathrm{ml}$ of EDA, but has an increasing effect in solutions buffered with hexamine or weaker with EDA. It has a tentative reaction with clodronate. Absorbances of the starting points differ because of the slight change in the amount of clodronate (ca. $5 \mathrm{ml}$ ) added. The amount of clodronate in a test series is the same.

\section{Conclusions}

The effects of the main substances of human urine on the reaction of clodronate and Th-EDTA-XO cause severe spectral interference, and therefore urine samples cannot be analyzed with those methods (spectrophotometric titration and spectrophotometric methods) that include detection with a spectrophotometer at fixed wavelength. However, the human eye is capable of detecting a wide spectral area simultaneously, and thus detect the total colour of the solution; this seems to make it possible to 
VIRTANEN ET AL.
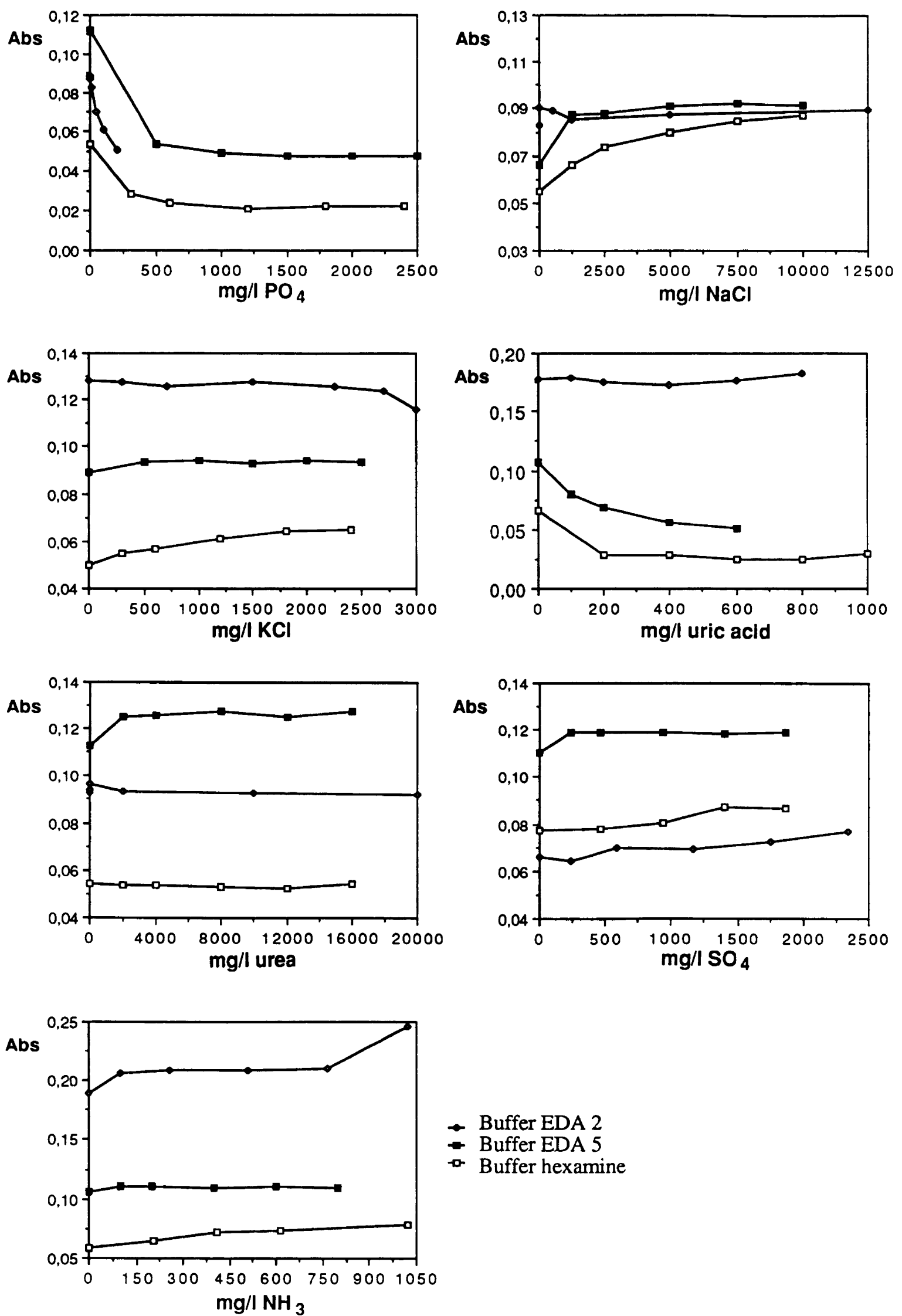

Buffer EDA 2

- Buffer EDA 5

$\rightarrow$ Buffer hexamine

Fig. 5. Effect of main substances in urine on the spectrophotometric method. 
detect colour changes in solution even though a fixedwavelength spectrophotometer is not capable of doing so. Therefore visual complexometric titration seems to be applicable to the analysis of urine samples.

All methods are applicable for quality control and purity determinations of the medicine at the medical factory.

\section{References}

1. Jurisson, S. S., Benedict, J. J., Elder, R. C., Whittle, R. and Deutsh, E. Inorg. Chem. 22 (1983) 1332.

2. Nardelli, M. and Pelizzi, G. Inorg. Chim. Acta 80 (1983) 259.

3. Shinoda, H., Adamek, G., Felix, R., Fleisch, H., Schenk, R. and Hagan, P. Calcif. Tissue Int. 35 (1983) 87.

4. Dietsh, P., Günther, T. and Röhnelt, M. Z. Naturforsch. 31 (1976) 661 .

5. Elomaa, J., Blomqvist, L., Porkka, L., Holmström, T.,
Taube, T., Lamberg, A. C. and Borgström, G. H. Lancet 1 (1985) 1155

6. Kaila, L. Protonation and potassium, magnesium and sodium complexes and thermal characteristics of clodronate, Thesis, University of Oulu, Department of Chemistry 1988.

7. Virtanen, V. and Lajunen, L. H. J. Acta Chem. Scand. 47 (1993) 89.

8. Virtanen, V. and Lajunen, L. H. J. Talanta 40 (1993) 661.

9. Pohjala, E., Nupponen, H. and Vepsäläinen, J. (Leiras Oy) PCT Pat. Appl. (1989) WO 90/15806.

10. Van der Walt, T. N. and Fourie, P. J. Appl. Radiat. Isot. 38 (1987) 158.

11. Vogel's Textbook of Quantitative Inorganic Analysis, 3rd ed., Longman Scientific \& Technical, Essex 1987, pp. 767-768.

12. D'Amour, F. E. Basic Physiology, 3rd impression, University of Chicago Press, Chicago, IL 1963, p. 428.

13. Pribil, R. and Vesely, V. Talanta 14 (1967) 591.

14. Pohjola, E. and Lauren, L. (Leiras Oy). Personal communication.

Received February 25, 1993. 